\title{
Prototulbaghia, a new genus of the Alliaceae family from the Leolo Mountains in Sekhukhuneland, South Africa
}

\author{
Vosa* Canio Giuseppe \\ Linacre College, Oxford
}

\begin{abstract}
A new monotypic genus of the Alliaceae family, Prototulbaghia, endemic of an isolated range of mountains in N.E. South Africa, is described and illustrated.
\end{abstract}

Key words: family Alliaceae, Monotypic genus, Prototulbaghia.

\section{INTRODUCTION}

The existence of the taxon which is the object of the present study has been in the public domain for a very long time. Its existence was announced by VAN WYK and SMITH, with photographs, showing the flowering plant in situ, in the valuable book: Regions of Floristic Endemisms in Southern Africa (2001). Its ecology and habitat has been described by CRAIB \& SIEBERT (2002) again with photograph of the habitat and of the flower. Seeds are freely available for sale on at least two seed merchants internet sites and the plant is widely cultivated by bulbous plant collectors.

The present study is to formally describe the new taxon with notes on its geographical position, its ecology, cytology and relationship both morphological and cytological with other members of the same family.

The geographical and climatological position - The Leolo Mountains, where the new taxon is to be found, are located in the Sekhukhuneland region, which lies within the Limpopo and Mpumalanga Provinces of Northern South Africa, in the former black homeland of Lebowa, and are a recognized Centre of Floristic Endemism (VAN WYK and SMITH 2001).

The range has a north to south orientation somewhat parallel to the north-eastern Drakensberg Escarpment and climatically is in its rain shadow. The major part of Sekhukhuneland is hot

\footnotetext{
* Corresponding author: Dipartimento di Biologia, Via Luca Ghini, 56126 - Pisa (Italy); e-mail caniovosa@tin.it
}

and dry but the Leolo range, which arrives at 1932 $\mathrm{m}$ above sea level, raises more than $1000 \mathrm{~m}$ above the arid and hot valleys, receiving the highest rainfall of the area from November/December to April.

Together with the mist, which is quite common especially on the summit of the Leolo Mountains, this climatic regime ensures the existence and the evolution of a diverse flora rich in endemics (Siebert 1998; van Wyk and SMith 2001; SiEBert et al. 2002).

The existence of a number of sites of open-cast minings and other deleterious human activities, such as heavy grazing, undermines the biodiversity of the special flora and fauna of the Leolo Mountain Range, to such an extent that drastic measures of conservation are urgent and necessary.

The plant belonging to the new taxon has been found so far only in the south of the range on the summit plateau, in seepage areas formed between sheets of exposed norite rock, in soil derived from its erosion, at an altitude of more than $1800 \mathrm{~m}$. above sea level. Such areas may be quite parched during the dry winter but in the rainy season, in the summer, they are more or less permanently wet, if not saturated in certain periods.

This alternation of very dry and wet periods is proper of certain desert or semidesert regions. The discovery and the first collection of the new species was made by Dr. Stefan Siebert in December 1999. Stefan brilliantly conducted the first comprehensive floristic-ecological study of Sekhukhuneland and collected material of several new plant taxa endemic to the region (SIEBERT 1998). 


\section{MATERIALS AND METHODS}

The material consisted in a number of growing plants from tiny seedlings to mature specimens, mostly collected "in situ" in two different locations, and also from plants grown from seeds obtained from a commercial source in November 2005. They were cultivated in clay pots in a compost of peat, sand and ordinary garden soil and kept in a cold greenhouse.

For the mitotic preparations, actively growing root-tips, collected at about 11 o'clock a.m., were pretreated in an aqueous solution of $0,05 \%$ colchicine for four hours at the same temperature of the growing plants and fixed overnight in 1:3 glacial acetic-acid/absolute alcohol. After a short hydrolysis in $1 \mathrm{~N}$ hydrochloric-acid at $60^{\circ} \mathrm{C}$, the meristematic part of the tip was squashed in a drop of $1.5 \%$ orcein in $45 \%$ acetic-acid or after 6 ' hydrolysis, the tips were stained in Feulgen for 1 hour and squashed in 1.5\% acetic-orcein.

Photographs of the living material and of the cytological preparations, were taken with a digital camera. They are grouped together in Plate I.

\section{RESULTS AND DISCUSSION}

Descriptive notes - The new taxon is a very small deciduous plant (Fig. 1) with an alliaceous smell when crushed and very thin, shiny, dark green leaves with peculiar hooked tips (Fig. 3). The emerging young leaves have coils which gradually relax but remain as thickened hooks on the mature leaves. This feature, owing to the plants growing in more or less loose soil, might be relevant to a kind of asexual propagation, especially at the young seedling stage.

The flowers (Figs. 1 and 2), which face upwards showing the deep yellow anthers, appear just after the start of the summer rains, usually in November, and are quite small, from 5 to a maximum of 6-7 $\mathrm{mm}$ in length from the tips of the outer perianth segments to the pedicels. They are white in colour with often a pink or purplish tinge on the outside and especially on the keel of the outer perianth segments and last only one day. The flowers usually open in the morning, never fully opening, remaining somewhat campanulate and fading to deep pink to magenta in colourin the late afternoon (Fig. 4). When a plant starts flowering, at least in cultivation, there will be at least one flower open every day for about a week to ten days. There is then a period of rest lasting a few days and the plant starts flowering again.
The flowering season may last all summer. In the wild, the new taxon appears to produce a large number of seed capsules pointing, perhaps, to a certain degree of self-fertility. The character of dimorphic winged staminal filaments is common in the family Alliaceae especially in the genus Allium and also in some of the related American genera. The similarities of the new genus with Allium, in a way, may be tentatively interpreted as it being a kind of a relic, intermediate between the latter and Tulbaghia, making it a sort of transitional stage between the two genera. In any case, the large size of the membranaceous expanded dorsal wings of three of the staminal filaments, which may be termed petaloid and coalesce at the edge with the three other simple filaments, forming a pseudo-corona and other characteristics are peculiar of our new genus.

Throughout its distribution area on the Leolo's Mountains Range, the new taxon seems to show hardly any variability. This lack of variability may be due to its apparent status of a paleo-endemic entity, now restricted to a homogeneous environment of seepage areas at relatively high altitude (Stefan Siebert 2006, in litteris).

Ecology and distribution - It is altogether intriguing and provocative to consider the existence in Southern Africa of a monotypic genus cognate to Tulbaghia and we can exclude the possibility of an accidental introduction on the line of some weedy species of Nothoscordum, notably N. borbonicum, of South American origins.

In this context, it is perhaps pertinent to consider the history of human settlements and activities in the area where our entity is found about 20 square kilometres (Craig and Siebert 2002, personal communication).

Although the region is inhabited by the mainly herders and pastoral Pedi tribe, it is nevertheless known that very few black people have ever lived permanently in, or near to, the area of distribution of the new genus. What is really a mistery is why the taxon in question, which is very conspicuous when its dense stands are in full bloom in November-December, has not been noticed or collected before 1999. Thus, given that its white-pinkish flowers facing upwards showing the bright yellow anthers are quite apparent, it is altogether strange that, to the best of our knowledge, there seem not to exist any previous record of observation nor of collection of the plant under whichever name.

Perhaps, the following hypothetical scenarios may have played a role in the plant being overlooked by field botanists, very few of whom, in 

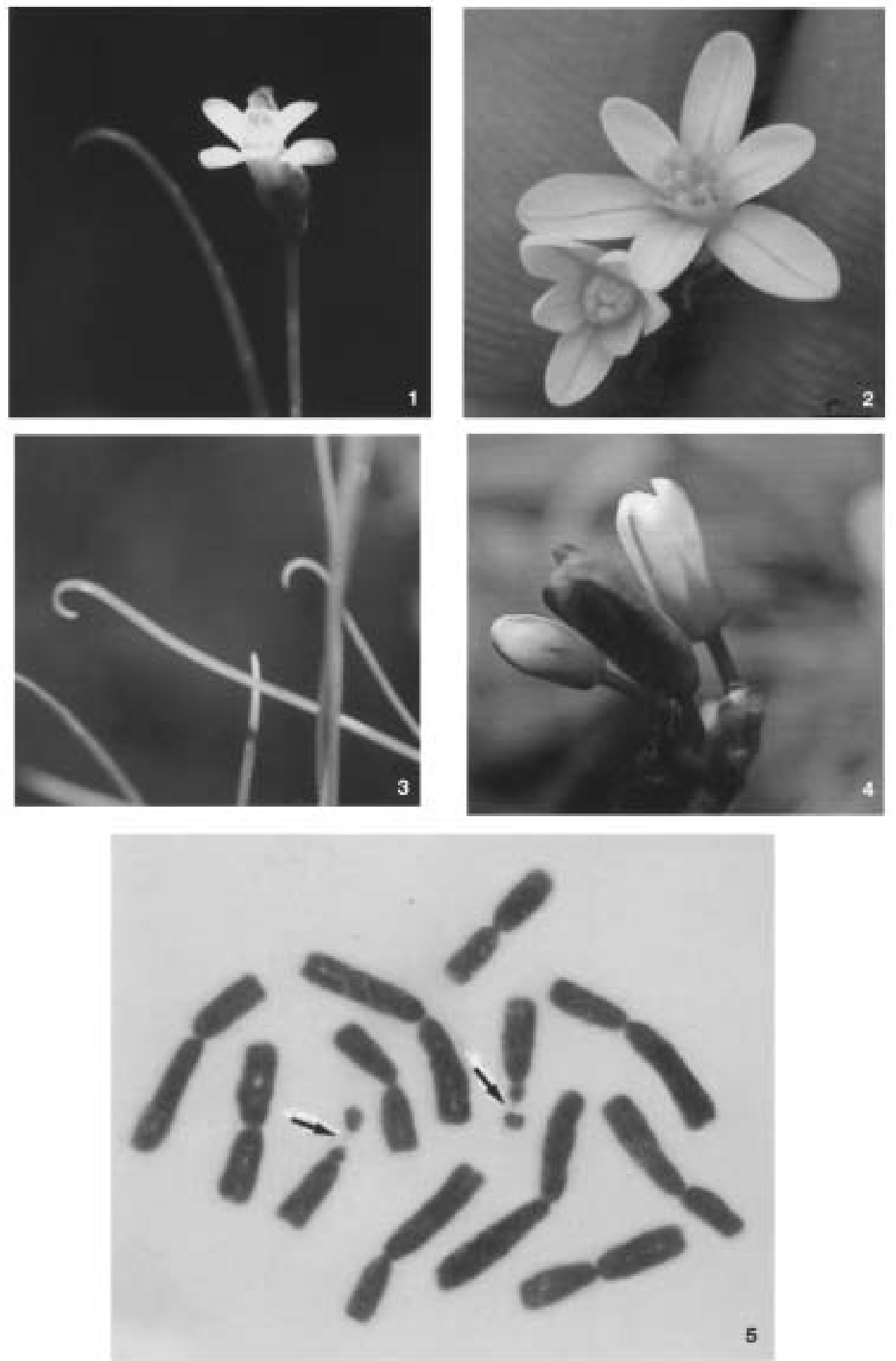

Fig. 1 - Inflorescence of Prototulbaghia siebertii (x 2). Fig. 2. Close-up of the flowers of P. siebertii (x 4). Fig. 3. The peculiar hooked leaves of the new genus (x 2). Fig. 4. The deep pink colour of the fading flowers in P. siebertii. Note the light green "calyx" and the greenish stripe which mark the keel of the outer perianth segments of the unopened flowers ( $\mathrm{x}$ 4). Fig. 5. Mitotic metaphase in P. siebertii $(2 \mathrm{n}=2 \mathrm{x}=12)$. The nucleolar constrictions (arrows) are located distally on the short arm of the smallest chromosomes of the complement. They are just visible as filaments connecting the short arm with the small "satellites" (x 2740). Figs.2 and 4 courtesy of Dirk Wallace. 
any case, seem to have visited the top of the Leolo Mountains prior to 1999. 1 - A factor to be considered is that Sekhukhuneland lies in the former black homeland of Lebowa and that, even in the comparatively recent past, hardly any botanist ever visited the area. 2 - The flowering time of the new taxon coincides with that of Zantedeschia jucunda (Araceae), a rare Arum Lily with very showy yellow inflorescences which is also endemic to the summit plateau of the Leolo Mountains. It is possible that the attention of visiting botanists were so distracted by this spectacular plant, that the comparatively less showy and more localized stands of our taxon were overlooked. 3 The confinement of the new taxon to temporary seepage areas may indeed result in irregular flowering. In fact, the first collection was made after particularly good spring rains and perhaps the occasional availability of abundant moisture explains the abundant flowering of the species at the time of discovery. During dry seasons, which in the area are more common that wet ones, plants may flower more erratically, thus rendering them much less conspicuous. 4 - Another, perhaps less likely explanation, might be a rapid expansion of the size of the populations owing to some kind of recent environmental changes. Such changes may imply a drastic reduction in number or of the disappearance of serious competitors or predators or the sudden appearance of a more efficient pollinator.

Differences, similarities and parallelisms - It is certain that there are some important morphological differences between our plant and Tulbaghia. These differences involve the existence, in all species of Tulbaghia, of a perigonial tube and of a true, often quite fleshy corona formed, in the light of our findings in the new taxon, by a morphological evolution of the staminal filaments, together with an outgrowth of the perianth. Other differences are to be found in the position of the anthers in two whorls, one inside the perigonial tube at the level or just above the stigma and the other more or less near the mouth of the corona in Tulbaghia while, in the new taxon, where the perigonial tube is very much reduced and insignificant, the anthers are all at the same level or just protruding, together with the stigma, from the top of the coalescing filaments which form a kind of pseudo-corona.

These morphological differences neatly separate our taxon from Tulbaghia, hence the proposal of a new genus.
On the basis of our findings, we opine that the kind of staminal structure found in our new genus is a possible intermediate stage towards a proper fleshy corona as in Tulbaghia. There remains the interesting problem of the peculiar ecological and taxonomic position of the proposed new genus. These peculiarities may perhaps warrant the suggestion of a possible reverse trend as an alternative hypothesis to its morphological evolution. Thus, taking into account this trend, we can envisage the reduction, due a strong selective pressure, from the usually fleshy corona of Tulbaghia, into the elaborate staminal structure of the new taxon. Therefore, we may consider, as adaptive characters, the elongation of the coalescing petaloid and simple staminal filaments, forming a kind of pseudo-corona, and the protrusion of the anthers at the same level of the stigma, together with the characteristic upward facing flowers of our new taxon. Such complex adaptive characters must be related to the special ecological situation in which our taxon has evolved in isolation and may involve the existence of an endemic co-evolved pollinator.

Of course, the acceptance of the hypothesis of a reverse trend signifies the complete overturning of our erstwhile speculations that consider the Leolo Mountains taxon a precursor of Tulbaghia and, instead, would make it a later derivative. This interpretation, in spite of the diverging floral characters, would place the entity in question taxonomically and philogenetically clearly within the genus Tulbagbia. In any case, though, the results of our studies, both morphological and cytotaxonomical, have led us to consider and put forward, as the most probable, the first hypothesis of a precursor of Tulbaghia for the Leolo Mountains plant.

Accordingly, we hypothesize that the existence of a precursor of Tulbaghia, indigenous of the Leolo Mountains Range in Sekhukhuneland, is altogether reasonable, especially if we take into account, besides the morphological details, chromosome number and morphology (Fig. 5).

The chromosome complement of the new taxon is similar to that of Group 5 of Tulbaghia (VosA $1975 ; 2000$ ) which includes five species: $T$. leucantha, T. natalensis, T. verdoorniae, T. coddii and T. galpinii. This latter species is morphologically peculiar and represents a special case which may be important in our effort to understand the isolated existence of the new taxon.

T. galpinii, unlike any other known species of Tulbaghia, possesses a corona composed of three scarcely fleshy main lobes, each subdivided, about half of their length, into two smaller acuminate 
lobes. T. galpinii is a very small plant with rather thin leaves, found only in a few very restricted areas of the Eastern Cape and all accessible living and herbarium collections are remarkably uniform. It is found in a homogeneous environment of sandy soil in rocky areas, often associated with dwarf clumpy euphorbias which provide a kind of protection from herbivores. Experiments on cultivated material, originally collected in four separate locations in its area of distribution, carried out over several years, have established that $T$. galpinii is almost completely self-fertile. This character, which involves inbreeding, has placed this species into an evolutionary cul-de-sac. This, of course, might account for the "primitive" features such as the thin and deeply lobed corona.

T. galpinii has a short perigonial tube and seems not to have any morphologically close relatives. The relatively small area of distribution indicates that this species may be at the end of a nearly estinct evolutionary trend. The parallel with the new taxon is evident: similar karyotype, very restricted distribution, a peculiar 'corona', a short perigonial tube and is supported by the study of karyotype evolution in Tulbaghia (Vosa 1975; 2000).

I take pleasure in naming the new taxon after its discoverer, Dr. Stefan Siebert, in recogniuion of his considerable contribution to the botany and ecology of the Sekbukbuneland Centre of Floristic Endemism (SIEBERT 1998).

\section{TYPIFICATION}

\section{Prototulbaghia siebertii gen. et sp. nov. \\ Chromosomatum numerus: $2 \mathrm{n}=2 \mathrm{x}=12$}

Diagnosis - Planta pusilla, speciebus generis Tulbaghiae affinis a quibus tamen precipue differt foliis apice revolutis et tubus ex perigonii nullus per filamentis contiguis coronam similantibus.

Descriptio - Planta bulbo conico rbizomati brevissimo insidente, circa $15 \mathrm{~mm}$ diametro, ad $25 \mathrm{~mm}$ longo, tunicis membranaceis lilacinis obtecto. Radices parce carnosae. Foliia 3-6 erecto-patentia, nitida, atro-viridia, 10-15 cm longa, 1-1,5 mm lata, acuta apice revoluta. Scapus gracilis, foliis aequilongis vel iis paulo brevior, 3-8 florus. Bracteae membranaceae, atro-purpureae, sub anthesis scariosae. Flores erecti, tepala alba in 2 verticilli disposita, inferne adnata in calix hemisphaericus 1,5 mm longo, superne libera, marginibus dilute purpureis; terna verticilli inferioris oblonga, $4 \mathrm{~mm}$ longa, $2 \mathrm{~mm}$ lata, carinata, carina dilute purpurea, superne striata nervo mediano viridi vel dilute purpureo; terna verticilli superiora oblonga, $3,5 \mathrm{~mm}$ longa, ad 1,7 mm lata, superne striata nervo mediano, viridi vel dilute purpureo. Stamina in 2 verticilli disposita, filamentis contiguis corona simulantibus, difformibus, ternis verticilli inferioris laminaribus petaloideis, eroso-obtusis, ternis verticilli superioris subfiliformibus; antheris $1 \mathrm{~mm}$ longis, flavis. Ovarium subglobosum, tubo perigoniali partim adnatum, triloculare, ovulis 2-4 in singulo loculo. Stylus $3 \mathrm{~mm}$ longus, subfiliformis. Stigma capitatum, minute papillatum, nitens. Capsula matura mitriformis, loculicida.

Description - Rootstock a bulb-like, elongated, pear-shaped corm on a very short poorly defined rhizome, $15 \mathrm{~mm}$ in diam. and about 20 to $25 \mathrm{~mm}$ long. Roots not very numerous, a little fleshy. Leaves 3 - 6 erect to spreading, bright green with a purplish membranaceus base, semiterete, fleshy with a not very distinct double keel and with a distinctly acute and hooked apex, $10-15 \mathrm{~cm}$ long and about $1,0-1,5 \mathrm{~mm}$ broad. Leaves from 10 to 15 $\mathrm{cm}$ long with their tips somewhat coiled outwards when young, the coil relaxing as the leaf develops but remaining as a tickened hooked tip in mature leves. Peculiarly, it is difficult if not impossible, without uprooting them, to pass a finger through a clump of plants because of the entangled hooked leaf-tips. Spathe valves 2, the longest about $4 \mathrm{~mm}$ long, purplish-brown in colour, scariose at anthesis, sub-tending the inflorescence only at the emergence of the flower-scape then gradually drying out. Floral scape thin, as long or a little shorter than the leaves, carrying 2 to 4 flowers. Pedicels about $7 \mathrm{~mm}$ long, usually greenish-purple in colour. Flowers facing upwards, about 5,5 $7 \mathrm{~mm}$ long overall, developing and opening in succession over a few days, never fully opening and remaining somewhat bell-shaped with the outer segments flaring out rather more than the inner, opening about mid morning in bright sunshine and closing early in the afternoon, each flower lasting only one day, eventually fading pink to magenta as they age and close. Perianth segments connate for about $2 \mathrm{~mm}$ in their lower half forming a very short and scarcely evident light green calyx, outer segments about 4,5 $\mathrm{mm}$ long and $2 \mathrm{~mm}$ wide in their upper third, pinkish towards the tip at anthesis, gradually fading into white, spathulate with a well defined keel purplish towards the end and with a light pink mid-vein on the inside, inner segments about broadly oblongovate, spathulate, a little shorter than the outers 
and about $1,5 \mathrm{~mm}$ wide about their middle, greenish-hyaline in colour with a faint green mid-vein. Staminal filaments 6 , the three originating at the base of the inner perianth segments greatly dilated into oblong retuse-erose petaloid wings on their outward sides, the three facing the outer perianth segments thread-like, fused to the hedges of the petaloid filaments for little more than half of their length. Thus, the six filaments together form what appears as a cylindrical pseudo-corona. Anthers bright yellow, sagittate, about $1,5 \mathrm{~mm}$ long and $0,3 \mathrm{~mm}$ wide, attached to the tips of the threadlike filaments and about the middle of the petaloid wings on a short filaments, their tips showing at the level or just above the rim of the pseudo-corona. Style about $3 \mathrm{~mm}$ long, reaching or just above the level of the dehiscing anthers, rather thin. Stigma small, capitate with the tip covered by minute shiny papillae. Ovary about $1 \mathrm{~mm}$ long, shiny green, about as long as the calyx formed by the coalescing perianth segments, obovate, triangular in shape with rounded corners in section. Ripe capsule triangular, mitre-like with the dried up remains of the perianth segments at its base and carrying at its top the withered style.

Holotype: A. E. van Wyk \& S. Siebert, 1304 (PRU)! Limpopo - 2430 CA (Pilgrim's Rest): Leolo Mountains, Sekhukhuneland, ca. $15 \mathrm{Km}$ from Schoonoord on mountain road. Growing in seepage areas of grassland in poorly drained soil overlying norite rock, in full sun in a gentle northfacing slope $(04 / 12 / 2000)$.

Other material seen:

a) - A. E. van Wyk, 13577 (PRU), Limpopo 2430 CA (Pilgrim's Rest): Leolo Mountains, Sekhukhuneland, summit area near Maope. Growing in seepage areas associated with exposed rock sheets $(11 / 12 / 2000)$.

b) - A. E. van Wyk, 13581 (PRU), Limpopo 2430 CA (Pilgrim's Rest): Leolo Mountains, Sekhukhuneland, summit area near Maope, grow- ing in heavily grazed grassland in seepage areas associated with exposed rock sheets (11/12/2000).

The holotype and the other specimens are kept in the H.G.W.J. Schweickerdt Herbarium (PRU), Botany Department, University of Pretoria, South Africa.

Acknowledgements - I wish to thank all the people in South Africa and especially the staff of the South African Biodiversity Institute (S.A.N.B.I.) for their kind assistance and hospitality during my visit to the $\mathrm{Na}$ tional Herbarioum in Pretoria. I wish to express my deep gratitude to the Curator of the H.G.W.J. Schweickerdt Herbarium of the Botany Department of the University of Pretoria, for assistance during my stay in South Africa. I wish to thank also Dr. R. M. Baldini of Florence, Italy, for linguistic collaboration.

\section{REFERENCES}

Craib C. and Siebert S., 2002 - A new genus related to Tulbaghia from seepage areas on the summit of the Leolo Mountains in Sekhukbuneland, South Africa. Herbertia, 57: 85-90.

SiEBERT S.J., 1998 - Ultramafic substrates and floristic patterns in Sekhukbuneland, South Africa.

M. Sc. Thesis, University of Pretoria, South Africa.

Siebert S.J., Victor J.E., van WyK A.E. and BREDENKAMP G.J., $2002-A n$ assessment of threatened plants and conservation in Sekbukbuneland. Plant Life, 26: 7-18.

Vosa C.G., 1966a - Chromosome variation in Tulbaghia. Heredity, 21: 305-312.

Vosa C.G., 1966b - Tulbaghia bybrids. Heredity, 21: 675-687.

VosA C.G., 1975 - The cytotaxonomy of the genus Tulbaghia. Annali di Botanica (Roma), 34: 47-121.

Vosa C.G., 2000 - A revised cytotaxonomy of the genus Tulbaghia. Caryologia, 53: 82-112.

WyK A. E. van and Smith G. F., 2001 - Regions of Floristic Endemism in Southern Africa. Undau Press, Hatfield, South Africa.

Received February $8^{\text {th }}$ 2007; accepted April $15^{\text {th }} 2007$ 